\title{
Group Factors of Voluntary Employee Turnover in Organizations from IT Sector
}

\section{Anna KOSZELA}

\author{
Wroclaw University of Science and Technology, Wroclaw, Poland; anna.koszela@pwr.edu.pl
}

\begin{abstract}
The research conducted so far on the phenomenon of voluntary employee turnover has still not achieved the desired method of keeping employees, especially in IT organizations. Therefore, it is important to expand the research by presenting new concepts that have not been developed so far, focusing on factors considered so far to be unclear in the context of voluntary employee turnover. This article aimed to present group factors relevant to mitigating voluntary employee turnover in IT organizations. In the context of factors related to the work on the team, identified the following factors: styles of leadership inspiring and supporting leader like transformational or servant leadership, manager relationship, co-worker's relationship - emotional and instrumental support and internal communication, which cannot be ineffective and inefficient. A review of the literature considering group factors mitigating voluntary employee turnover shows that proper care for employees at the group level leads to measurable benefits for the whole organization.
\end{abstract}

Keywords: voluntary employee turnover; group factors; management

JEL Classification: D29; G30; M12

\section{Introduction}

The IT sector is one of the fastest-growing sectors due to growing technological needs (Henderson, 2012). The current crisis caused by the pandemic of COVID-19 shows that the technological need has become even higher every day, as almost all our lives have been moved online. During the previous crisis, wherein the IT industry, the decrease in turnover rate was not noticeable, although it is natural that during the crisis, the turnover rate is in recession (Lo, 2013). To meet the growing requirement for technology requirement, more and more IT companies are being established on the market, thus significantly increasing the demand for IT employees (Dohm \& Shniper, 2007), whose deficit is constantly observed (Rong \& Grover, 2009). The short-staffed causes that organizations have to compete strongly on the market for the interest of qualified and talented employees (McGee \& Thyfault, 1998). Ensuring appropriate working conditions for employees will result in benefits for the organization because it is the employees who are key to maintaining the competitiveness of the organization (Bieńkowska \& Ignacek - Kuźnicka, 2018). It can be concluded that the success of IT organizations can be determined by their strategy to manage voluntary employee turnover (VET) (Purohit, 2016; Lo, 2015). This strategy should primarily focus on finding the causes of employee dissatisfaction that may cause an intention to leave the organization. However, it is difficult to identify the causes of turnover and, because are strongly dependent on many conditions, so it seems reasonable to focus on the chosen sector 
when studying rotation. In this article, the author identifies group factors influencing VET in the IT industry, which seem to be of significant importance in shaping it. The model of work in the IT industry is based primarily on working in teams, it is the team that directly affects the behavior and perception of the organization by the employees, and thus may contribute to their desire to leave the organization (Tarricone \& Luca, 2002). Relationships with coworkers and relationships with supervisors, if based on conflict, are bound to result in intense dissatisfaction and negative feelings for the organization (Greene \& Organ, 1973; Johnson \& Graen, 1973; Johnson \& Stinson, 1975). If a leader only requires an employee to be more efficient and effective, without supporting the employees in development and without giving them a sense of job security and trust, they may leave the organization (Bennis \& Nanus, 1985; Fairholm, 1994; Zand, 1997). Therefore, in interpersonal relations, communication is also important, because it is the weakness of its process that can lead to a lot of misunderstandings, which will lead to conflicts and dissatisfaction. Although these factors have so far been considered individually in the literature in the context of an employees' behavior, their job satisfaction, or decreasing the intention to leave, the researchers have not so far grouped them as group factors influencing VET. Given the identified research gap, the article aims to present a literature review on factors influencing VET and justify their importance in preventing intention to leave, and to inspire further consideration and research.

\section{Voluntary Employee Turnover}

The review of the literature confirms that the aspect of employee turnover has been analyzed for a long time (Hom et al., 2017) due to the fact, that employee turnover is an integral part of Human Resources Management (HRM) in an organization (Listwan, 2010). Personnel fluctuation is defined as a kind of variability, lack of constancy, or periodical fluctuation - thus, it defines a certain exchange of employees or loss of personnel (Cybulski, 2008). Nevertheless, the concept is very heterogeneous, as it includes any restrictions on the number of employees, suspension of recruitment, disciplinary layoffs, or outplacement - i.e., controlled layoffs, but also natural leaves of employees from the organization, such as retirement or VET (Bar, 1994). The current trend in HRM indicates that the loss of experienced employees and the loss of their tacit knowledge, the so-called "loss of human capital", can cause a risk to the organization because the recruitment of new employees consumes significant financial resources and it will take a long time to rebuild the knowledge of an experienced employee (Thatcher et al., 2002). Currently, research shows that it is highly skilled, highly efficient employees, due to their specialized knowledge, who most often decide to leave the organization because they are aware of their skills, looking for new opportunities and new challenges (Pocztowski, 2007). So far, many concepts related to VET have been developed. Purohit (2016) considers turnover as a rate of the number of employees, who leave the organization voluntarily and the organization must replace in a given period to the average number of employees employed in the organization. Moreover, the author considers the turnover rate in many ways but especially notes that the main risk for organizations is especially the VET of high-skilled employees (Purohit, 2016). Porter and 
Steers (1973) in their turnover model focused on "turnover intention" and "intention to leave", defined as the next step in the process of leaving after experiencing dissatisfaction in the organization (Aburumman et al., 2010), a step that can lead to actually leaving the organization. Matz and colleagues (2013) define intention to leave as an intentional and aware decision to leave an organization. Intention to leave an organization is a much better indication of an employee's actual turnover than job satisfaction or affective commitment (Rubenstein et al., 2017; Schaap \& Olckers, 2020). For an organization, information about the intention to leave seems to be very helpful as it forces the organization to take steps to influence the employee's decision. However, it is also important to identify those factors that cause such a high degree of dissatisfaction among employees that they are more likely to leave the organization. This is a big challenge for modern HR managers.

\subsection{Factors Related to the Employee Turnover}

For many years, researchers have been developing models to explain the turnover phenomenon, but the number of such models may indicate that they are not globally applicable. March and Simon (1958) presented VET is a phenomenon that depends mainly on the ease of changing jobs - that is, the possibility of employment on the job market and the goal that employees have when changing jobs (March and Simon, 1958). However, the advisability of changing jobs depends to a certain extent on the financial benefits and rewards currently offered by the organization (Steers \& Mowday, 1981; Dreher, 1982; Gerhart \& Milkovich, 1992;). According to the March and Simon model (1958), this influence of the factors determining the intention to leave is not direct, as it mediates through job satisfaction. Steers and Mowday (1981), in addition to the market and economic conditions, pointed to the indirect cause of VET, employee expectations for work, and the values that directly affected job satisfaction and work engagement, and organizational commitment. However, many of the factors included in the model were directly related to the individual characteristics of the employee. On the other hand, Price and Mueller (1981) focused on their model only on workrelated factors. The causes of indirect turnover were primarily seen in autonomy, fairness, pay levels, promotion opportunities, work routines, social support, and training opportunities. The analysis presented by Price and Mueller (1981) seems to be in line with Porter and Steers (1973), who saw an intention to leave the organization as an organizational factor for dissatisfaction. Today, it is still believed that as long as an employee is satisfied with their job, the organization provides them with a sense of stability and the relationship with their manager is satisfactory, the employee will not feel the need to search for a new job. Unfortunately, it is more and more often observed that the level of turnover is increasing among employees whose profession is in high demand in the job market. This group includes knowledge workers (Trevor et al., 1997) so employees of the IT industry, which is considered to be one of the more attractive sectors on the job market, still facing a much more dynamic increase in demand for IT specialists than they are available. The specificity of this sector and the heterogeneity and multiplicity of models indicate that it is necessary to conduct a separate analysis of the reasons for VET in terms of its characteristics. 


\subsection{Voluntary Employee Turnover in IT Organizations}

Purohit (2016) noted that the current actual turnover rate is close to $25 \%$ because more and more IT organizations are moving into the Indian market due to the low cost of retention (Purohit, 2016). Studies conducted by Lacity et al. (2008) show that the problem of VET in India is even stronger and the rate often exceeds $30 \%$. Research conducted in Sri Lanka also confirms the growing problem of VET. The results of these studies show that only $50 \%$ of employees declare their intention to stay in the current organization while as many as $80 \%$ of employees expect certain job changes, i.e., career development through promotion (Jinadasa \& Wickramasinghe, 2005). A study conducted in China shows that the turnover rate can reach up to $50 \%$, which significantly increases the cost of recruiting employees and also limits the development of the organization (Listwan, 2010). In turn, a study conducted by the Malaysian Federation of Employees showed that in recent years, IT organizations have achieved the highest turnover rates - up to 75\% (Hassan, 2014). Also, statistical studies conducted by the U.S. Department of Job Market confirm that the rate of VET from IT organization only in 2005-2006 increased by $7.2 \%$ and this trend is continuing (Von Hagel, 2009). As can be seen, the problem is real and these trends present a challenge for the management of IT organizations, taking into account the costs necessary to replace IT specialists (Korsakienè et al., 2015). Nevertheless, there is still too little research that concentrate on VET from IT organizations. Until now, researchers have focused more on research on VET in the banking, nursing, or accounting sectors (Von Hagel, 2009).

\section{Group Factors of Voluntary Employee Turnover in IT Organization}

There are many factors in the literature on VET that directly or indirectly affect intention to leave (March \& Simon, 1958; Steers \& Mowday, 1981; Price \& Mueller, 1981). In Table 1, the author presented the concept of dividing the factors influencing VET the IT sector directly related to work group.

Table 1. Group factors of IT employee turnover

\begin{tabular}{|c|c|}
\hline \multicolumn{2}{|c|}{ Group factors of IT employee turnover } \\
\hline Factor & Literature references \\
\hline Leadership & Sun and Wang, 2017; Parris and Peachey, 2013; Jaramillo et al, 2009; Turgut et al., 2007 \\
\hline $\begin{array}{c}\text { Manager } \\
\text { relationship }\end{array}$ & Cotton et al., 1986; Lee, 2004; Thwala et al., 2012; Foong, 2008; Longenecker and \\
Scazzero, 2003; McKnight et al. 2009
\end{tabular}

Group factors, by the author, are defined as the factors related to the employees' position in the team. Scarnati (2001) defines teamwork as a cooperation process that allows employees to achieve additional results (Tarricone \& Luca, 2002). Each team has common goals or tasks in which team members can develop effective, building up a good relationship and sharing knowledge and skills (Johnson \& Johnson, 1995, 1999; Fisher et al., 1997). Any conflict can disrupt the harmony of work in a team, reduce the employees' job satisfaction and 
productivity, and thus reduce the performance of the whole team and also increase the intention to leave the most talented employees (Greene \& Organ, 1973; Lyons, 1971; Johnson \& Graen 1973; Johnson \& Stinson; 1975). Often, among the reasons for conflict, there are some misunderstandings or communication problems within the team, in consequence, effective communication also has a significant role in team management (Spaho, 2013). Therefore, a leader should inspire his co-workers to perform and effectively solve problems and conflicts, because it can strengthen the effective synergy of the team (Bennis \& Nanus, 1985; Fairholm, 1994; Zand, 1997). Teams are an integral part of the organization, the perception of the organization's employees is often based on the perception of work in a group (Tarricone \& Luca, 2002). Based on the above considerations, the author has distinguished those factors, that will have a significant impact on VET as leadership style of team leader (Sun \& Wang, 2017; Parris \& Peachey, 2013), coworkers' relations (Fisher, 1985; Uhl-Bien et al., 2000; Tews et al., 2013), managers relationship (Cotton et al., 1986; Lee, 2004; Thwala et al., 2012), internal communication in the team (Kotter, 1996; Ballard \& Seibold, 2006; Kotter, 2012).

\subsection{Leadership}

Leadership has a significant impact in the context of building relations between an employee and a leader. The leader behavior, i.e., the way decisions are made and implemented, their communication skills, as well as their approach to people, empathy, and understanding (Van Dierendonck et al., 2014; Kashyap \& Rangnekar, 2016), influences an employees' behavior and attitudes - including their willingness to stay or leave the organization (Palanski et al., 2014, Wang et al., 2016; Turgut, 2017; Suifan et al., 2020). Mobley (1977) has long since recognized that employees will stay in their jobs if they receive adequate support from their manager. In the literature, one of the most effective styles of leadership indicated transformational leadership (Antonakis et al., 2003; Moynihan et al., 2012; Sun \& Wang, 2017). Bass and Avalio (1994) define this type of leadership as a four-dimensional model consisting of ideal influence, inspiration, individual consensus, and intellectual stimulation. Transformational leaders are models to follow who gain the respect and trust of their employees, communicate important and attractive organizational goals to their employees, and effectively motivate employees to work (Sun \& Wang, 2017). Such leaders are focused on supporting employee development, building strong relationships with them, and unconventionally resolving problems and conflicts (Bass 1998; Bass \& Avalio, 1994). Studies conducted so far confirm the negative relationship between transformational leadership and VET (Wang \& Sun, 2016; Khan, 2015; Lim et al., 2017). Another type of leadership that has been identified in the literature as supporting and positively influencing employee behavior is servant leadership (Dutta \& Khatri, 2017). This leadership style has a positive impact on employee trust in the leader (Sendjaya \& Pekerti, 2010) and as a consequence increasing loyalty to the organization (Kool \& Van Dierendonck, 2012). Therefore, many researchers suggest that improving organizational loyalty has a positive impact on organizational commitment and weakens VET (Dutta \& Khatri, 2017). Therefore, the above considerations, show that a leader who tends to support their employees is 
effective in reducing their turnover (Parris \& Peachey, 2013; Jaramillo et al., 2009; Turgut et al., 2007).

\subsection{Manager Relationship}

The relationship between the employees and the manager seems to be an important HRM aspect, due to the growing significance of the employees in the organization and their growing rights (Lo, 2015). A supervisor's relationship with employees should focus on the proper communication process, correcting, shaping, and improving employees' knowledge, attitudes and behaviors to improve their job performance rather than punishing them for making mistakes (Megginson et al., 2001). Considering the much closer relationship between management and employee, positive treatment of employees by the supervisor may increase positive perceptions of organizational support (Rhoades et al., 2001; Joarder et al., 2011). As a result, research indicates that VET decreases and the employee's productivity, efficiency, and job satisfaction increase (Cotton et al., 1986; Lee, 2004; Thwala et al., 2012). Employees aspire to professional success through positive relationships with their supervisor, which can help to achieve organizational commitment and job satisfaction, and this indirectly reduces VET (Foong, 2008). Research conducted by Thatcher (2006) shows that satisfaction with the relationship with the superior has a positive, direct impact on motivation to work, while a negative perception of the superior has a direct impact on increasing the desire to leave the organization (Longenecker \& Scazzero, 2003). Other research conducted on a group of employees, also from the IT industry, indicated that employees' trust in leaders increases job satisfaction and lowers VET (McKnight et al. 2009). Therefore, support from superiors is necessary because it will keep the employees in the organization and motivate them to work (Bigliardi et al., 2005; Zhao \& Zhou, 2008).

\subsection{Coworkers Relationship}

Employees' relationships can be defined as the keeping of normal working relationships between employees, which can contribute to achieving satisfactory job performance, work motivation, morale, and, consequently, meeting organizational goals (Long et al., 2012). Fisher (1985) describes employee relationships as friendly and caring relationships that provide employees with emotional confidence and support in solving stressful situations. The truth is that the style of work, especially in the IT sector, is more and more challenging for employees because they often have to perform difficult tasks and work many hours in project teams (Lee, 2004). As a consequence, employees will have more social requirements and emotional needs to motivate them to work. There are arguments in the literature that high-quality interpersonal contacts cause a positive impact on employees' behavior (Uhl-Bien et al., 2000). Moreover, when it comes to employee support, it should be considered in two respects as instrumental support - focused on tasks and problem solving (Mossholder et al., 2005) - and emotional - focused on the person, the foundation of friendship and personal care (Beehr et al. 2000). According to Zohar (1994), the workload is one of the most stressful factors, while instrumental support can reduce the stress by reducing the workload of the coworker (Beehr et al., 2003; Viswesvaran et al., 1999) and reduce VET (Tews et al., 2013). 
Emotional support also seems to be effective in mitigating VET, especially among young employees for whom human relationships are more relevant (Tews et al., 2013). Building friendship in the workplace increases the worker's commitment because leaving would require building new relationships (Tews et al., 2013). Instrumental support, similar to emotional support, can mitigate some of the negative emotions associated with work exhaustion or burnout caused by growing requirements and responsibility at work (Brotheridge \& Grandey, 2002; Glomb \& Tews, 2004). Therefore, it seems to be urgent for organizations to include employees' characteristics during formulating project teams.

\subsection{Internal Communication}

Communication is a crucial factor in HRM, above all, it is important in human relations management (Barrett, 2006). The role of internal communication in an organization is to analyze how is the process of people communication in the organization and to develop an effective communication system (Grunig \& Dozier, 2002). It should also identify, create, and keep the connections that are beneficial for both the organization and its employees, on which the success of the organization will depend (Cutlip, 1985). Bevan and Bailey (1991) consider internal communication is the main factor in employee work motivation and job performance and has an important role in building an organization's competitive advantage (TariszkaSemegine, 2012). Therefore, poor communication, can cause many risks in terms of HRM, such as lack of employee involvement, leadership problems, and even increased VET (Kotter, 1996; Ballard \& Seibold, 2006; Kotter, 2012). Branham (2005) also suggests that poor communication between management and employees is one of the factors why employees decide to leave the organization. Effective managers listen to their employees, allow them to present their point of view, and involve them in the decision-making process - then the work proceeds smoothly and effectively (Mishra et al., 2014). Employees who describe communication as ineffective and inefficient show much more intention to leave the organization (Kim et al., 2010; Adebayo \& Ogunsina, 2011; Abdien, 2019). Ballard and Seibold (2006) recognized the indirect impact of communication on VET. The organizations, which have a satisfactory communication process create a supportive work environment for the employees to successfully perform their tasks, increase job satisfaction, and consequently reduce education and job training (Naz \& Gul, 2014).

\section{Discussion}

The considerations on VET in IT organizations, undertaken in the article, contributed to the identification of a specific group of factors that can significantly mitigate a VET of IT employees. The group factors included leadership, relationships with co-workers, relationships with managers, and internal communication. Transformational and servant leadership presented in the literature as the most effective in reducing VET was indicated as the most supportive style of leadership. Leaders who build trusting relationships and who inspire employees to develop their skills offer them a special learning environment, which results in increased employee loyalty to the organization, a higher sense of commitment to the organization, and consequently reduced VET (Wang \& Sun, 2016; Khan, 2015; Lim et al., 
2017, Dutta \& Khatri, 2017). The style of leadership thus influences the building of employeemanager relationships, as it is recognized that relationships do not necessarily have to be based on friendship, but trust and a sense of support are essential. Friendly relationships can be built with co-workers and it is precisely these relationships, largely among young employees, that have significantly reduced VET (Tews et al., 2013). Some employees expect emotional support from their co-workers, which will reduce the negative emotions caused by daily tasks, while others expect instrumental support, i.e., support in performing these daily tasks and reducing the employee's workload (Beehr et al., 2003). Internal communication seems to be complementary to teamwork relationships which, among the above factors, can support positive VET mitigation efforts (Iqbal, 2010). A literature review shows that it is possible to effectively mitigate VET already at the level of small groups in the organization. Therefore, managers should care for the best-qualified leaders who will inspire employees to develop and should select personnel to the team in that way to match not only the qualifications of other colleagues but also their character.

\section{Conclusions}

The article presents a literature review on a specific group of factors influencing employee turnover in IT organizations. This is an important phenomenon, given the everincreasing demand for skilled IT employees and the continuing shortage of them. The concept of group factors that will reduce VET and prevent problems of organization with resources is presented. It is very important to conduct further considerations on VET and to develop a new concept of the turnover model because the models developed so far cannot be used universally. Of course, only a specific group of factors was taken into account in the considerations, which could be qualified as group factors - related to teamwork. Therefore, it seems necessary to repeat the review in the context of organizational factors and job-related factors. Besides, the considerations presented should also be verified in practice, and based on the research, a model for VET in an IT organization should be developed. Despite the limitations indicated, the presented considerations on VET in IT organizations may become an inspiration for further considerations on the significance of this phenomenon.

\section{References}

Abdien, M. K. (2019). Impact of communication satisfaction and work-life balance on employee turnover intention. Journal of Tourism Theory and Research, 5(2), 228-238. https://doi.org/10.24288/jttr.526678

Aburumman, O., Salleh, A., Omar, K., \& Abadi, M. (2020). The impact of human resource management practices and career satisfaction on employee's turnover intention. Management Science Letters, 10(3), 641-652. https://doi.org/10.5267/j.msl.2019.9.015

Adebayo, S. O., \& Ogunsina, S. O. (2011). Influence of supervisory behaviour and job stress on job satisfaction and turnover intention of police personnel in Ekiti State. Journal of Management and Strategy, 2(3), 13. https://doi.org/10.5430/jms.v2n3p13

Antonakis, J., Avolio, B. J., \& Sivasubramaniam, N. (2003). Context and leadership: An examination of the ninefactor full-range leadership theory using the Multifactor Leadership Questionnaire. The leadership quarterly, 14(3), 261-295. https://doi.org/10.1016/s1048-9843(03)00030-4

Ballard, D. I., \& Seibold, D. R. (2006). The experience of time at work: Relationship to communication load, job satisfaction, and interdepartmental communication. Communication Studies, 57(3), 317-340.

https://doi.org/10.1080/10510970600845974 
Barrett, D. J. (2006). Strong communication skills a must for today's leaders. Handbook of business strategy. https://doi.org/10.1108/10775730610619124

Bass, B. M., \& Avolio, B. J. (Eds.). (1994). Improving organizational effectiveness through transformational leadership. Sage.

Bass, B. M. 1998. Transformational Leadership: Industry, Military, and Educational Impact. Mahwah, NJ: Erlbaum Associates.

Beehr, T. A., Jex, S. M., Stacy, B. A., \& Murray, M. A. (2000). Work stressors and coworker support as predictors of individual strain and job performance. Journal of Organizational Behavior, 21(4), 391-405. https://doi.org/10.1002/(sici)1099-1379(200006)21:4<391::aid-job15>3.0.c0;2-9

Bennis, W. G., \& Nanus, B. (1985). Leaders: The Strategies for taking charge. NewYork: Harper\& Row, Publishers. Bevan, R., \& Bailey, J. (1991). Lesley's Handbook of Public Relations and Communication.

Bieńkowska, A., \& Kuźnicka, B. I. (2018). Professional trainings of lawyers as an indication of their involvement in the performed work-results of empirical research. In Edulearn 18. 10th International Conference on Education and New Learning Technology (Palma, 2nd-4th of July, 2018): conference proceedings (pp. 7182-7190). IATED Academy. https://doi.org/10.21125/edulearn.2018.1695

Bigliardi, B., Petroni, A., \& Dormio, A. I. (2005). Organizational socialization, career aspirations and turnover intentions among design engineers. Leadership $\mathcal{E}$ organization development journal. https://doi.org/10.1108/01437730510617645

Branham, L. (2012). The 7 hidden reasons employees leave: How to recognize the subtle signs and act before it's too late. Amacom.

Brotheridge, C. M., \& Grandey, A. A. (2002). Emotional labor and burnout: Comparing two perspectives of "people work". Journal of vocational behavior, 60(1), 17-39. https://doi.org/10.1006/jvbe.2001.1815

Cotton, J. L., \& Tuttle, J. M. (1986). Employee turnover: A meta-analysis and review with implications for research. Academy of management Review, 11(1), 55-70. https://doi.org/10.5465/amr.1986.4282625

Cutlip, S., Center, A., Broom, G. (1985). Effective Public Relations. Prentice Hall, Englewood Cliffs. https://doi.org/10.1080/00913367.1979.10717979

Cybulski, K. (2008). Przyczyny i konsekwencje wysokiej fluktuacji personelu sprzedażowego.

Dohm, A., \& Shniper, L. (2007). Occupational employment projection to 2016. Monthly Lab. Rev., 130, 86.

Dreher, G. F. (1982). The role of performance in the turnover process. Academy of Management Journal, 25(1), 137147. https://doi.org/10.5465/256029

Dutta, S., \& Khatri, P. (2017). Servant leadership and positive organizational behaviour: The road ahead to reduce employees' turnover intentions. On the Horizon. https://doi.org/10.1108/oth-06-2016-0029

Fairholm, G. (1994). Leadership and the Culture of Trust. Praeger Westport. https://doi.org/10.1007/978-0-38784902-7_6

Fisher, C. D. (1985). Social support and adjustment to work: A longitudinal study. Journal of management, 11(3), 39-53.

Fisher, S. G., \& Hunter, T. A. (1997). Team or group? Managers' perceptions of the differences. Journal of Managerial Psychology, 12(4), 232-242. https://doi.org/10.1108/02683949710174838

Foong-ming, T. (2008). Linking Career development practices to turnover intention: The mediator of perceived organizational support. Journal of Business and Public Affairs, 2(1), 1-16. https://doi.org/10.1108/02683949710174838

Gerhart, B., Milkovich, G. T., \& Murray, B. (1992). Pay, performance, and participation. Research frontiers in industrial relations, 193-238.

Glomb, T. M., \& Tews, M. J. (2004). Emotional labor: A conceptualization and scale development. Journal of Vocational Behavior, 64(1), 1-23. https://doi.org/10.1016/s0001-8791(03)00038-1

Greene, C. N., \& Organ, D. W. (1973). An evaluation of causal models linking the received role with job satisfaction. Administrative Science Quarterly, 95-103. https://doi.org/10.2307/2391931

Grunig, J. E., \& Dozier, D. M. (2003). Excellent public relations and effective organizations: A study of communication management in three countries. Routledge. https://doi.org/10.4324/9781410606617

Hassan, R. (2014). Factors influencing turnover intention among technical employees in Information technology organization: A Case of XYZ (M) SDN. BHD. International Journal of Arts and Commerce, 3(9), 120-137.

Henderson, R. (2012). Industry employment and output projections to 2020. Monthly Lab. Rev., 135, 65. https://doi.org/10.21916/mlr.2013.39

Hom, P. W., Lee, T. W., Shaw, J. D., \& Hausknecht, J. P. (2017). One hundred years of employee turnover theory and research. Journal of Applied Psychology, 102(3), 530. https://doi.org/10.1037/apl0000103 
Iqbal, A. (2010). Employee turnover: Causes, consequences and retention strategies in the Saudi organizations. The Business Review, 16(2), 275-281

Jaramillo, F., Grisaffe, D. B., Chonko, L. B., \& Roberts, J. A. (2009). Examining the impact of servant leadership on salesperson's turnover intention. Journal of Personal Selling \& Sales Management, 29(4), 351-365. https://doi.org/10.2753/pss0885-3134290404

Jinadasa, L., \& Wickramasinghe, V. (2005, December). IT industry labour turnover: the reality. In Proceedings of the 10th International Conference on Sri Lanka Studies, University of Kelaniya, Kelaniya, December 16 (Vol. 18).

Joarder, M. H., Sharif, M. Y., \& Ahmmed, K. (2011). Mediating role of affective commitment in HRM practices and turnover intention relationship: A study in a developing context. Business $\mathcal{E}$ Economics Research Journal, 2(4).

Johnson, T. W., \& Graen, G. (1973). Organizational assimilation and role rejection. Organizational Behavior and Human Performance, 10(1), 72-87. https://doi.org/10.1016/0030-5073(73)90005-6

Johnson, D. W., \& Johnson, R. T. (1995). Social Interdependence - Cooperative Learning in Education. In B. Bunker, \& J. Z. Rubin (Eds.), Conflict, Cooperation, and Justice (pp. 205-251). San Francisco: Jossey-Bass Publishers.

Johnson, D. W., \& Johnson, R. T. (1999). Learning Together and Alone: Cooperative, competitive, and individualistic learning (5th ed.). Needham Heights: Massachusetts: Allyn and Bacon.

Johnson, T. W., \& Stinson, J. E. (1975). Role ambiguity, role conflict, and satisfaction: moderating effects of individual differences. Journal of Applied Psychology, 60(3), 329. https://doi.org/10.1037/h0076752

Lacity, M., Rudramuniyaiah, P., \& Iyer, V. (2008). Understanding turnover among Indian IS professionals. In Offshore Outsourcing of IT Work (pp. 209-244). Palgrave Macmillan, London. https://doi.org/10.1057/9780230582965_7

Lee, P. C. B. (2004). Social support and leaving intention among computer professionals. Information $\mathcal{E}$ management, 41(3), 323-334. https://doi.org/10.1016/s0378-7206(03)00077-6

Lim, A. J. P., Loo, J. T. K., \& Lee, P. H. (2017). The impact of leadership on turnover intention: The mediating role of organizational commitment and job satisfaction. Journal of Applied Structural Equation Modeling, 1(1), 27 41. https://doi.org/10.47263/jasem.1(1)04

Listwan, T. (Ed.). (2010), Zarzadzanie kadrami. CH Beck.

Lo, J. (2015). The information technology workforce: A review and assessment of voluntary turnover research. Information Systems Frontiers, 17(2), 387-411. https://doi.org/10.1007/s10796-013-9408-y

Long, C. S., Perumal, P., \& Ajagbe, A. M. (2012). The impact of human resource management practices on employees' turnover intention: A conceptual model. Interdisciplinary journal of contemporary research in business, 4(2), 629-641.

Longenecker, C. O., \& Scazzero, J. A. (2003). The turnover and retention of IT managers in rapidly changing organizations. Information Systems Management, 19(4), 58-63.

https://doi.org/10.1201/1078/43203.20.1.20031201/40085.8

Lyons, T. F. (1971). Role clarity, need for clarity, satisfaction, tension, and withdrawal. Organizational Behavior and Human Performance, 6(1), 99-110. https://doi.org/10.1016/0030-5073(71)90007-9

Kashyap, V., \& Rangnekar, S. (2016). Servant leadership, employer brand perception, trust in leaders and turnover intentions: a sequential mediation model. Review of Managerial Science, 10(3), 437-461. https://doi.org/10.1007/s11846-014-0152-6

Khan, S. I. (2015). Transformational leadership and turnover intention: The mediating effects of trust and job performance (Doctoral dissertation, Bangkok University). https://doi.org/10.1080/15332845.2016.1202730

Kim, B. P., Lee, G., \& Carlson, K. D. (2010). An examination of the nature of the relationship between LeaderMember-Exchange (LMX) and turnover intent at different organizational levels. International Journal of Hospitality Management, 29(4), 591-597. https://doi.org/10.1016/j.ijhm.2009.10.025

Kool, M., \& van Dierendonck, D. (2012). Servant leadership and commitment to change, the mediating role of justice and optimism. Journal of Organizational Change Management. 25(3), 422-433. https://doi.org/10.1108/09534811211228139

Korsakienė, R., Stankevičienè, A., Šimelytė, A., \& Talačkienė, M. (2015). Factors driving turnover and retention of information technology professionals. Journal of business economics and management, 16(1), 1-17. https://doi.org/10.3846/16111699.2015.984492

Kotter, J. P. (2012). Leading change. Harvard business press.

Martin, G. (2009) Driving corporate reputations from the inside: a strategic role and strategic dilemmas for HR? Asia Pacific J Human Res, 47(2), 219-235. https://doi.org/10.1177/1038411109105443 
March, J. G., \& Simon, H. A. (1958). Organizations. John Wiley \& Sons. New York.

Matz, A. K., Woo, Y., \& Kim, B. (2014). A meta-analysis of the correlates of turnover intent in criminal justice organizations: Does agency type matter? Journal of Criminal Justice, 42(3), 233-243. https://doi.org/10.1016/j.jcrimjus.2014.02.004

McGee, M. K., \& Thyfault, M. E. (1998), Congress mulls more foreign workers. Information Week, 694, 32-32.

McKnight, D. H., Phillips, B., \& Hardgrave, B. C. (2009). Which reduces IT turnover intention the most: Workplace characteristics or job characteristics? Information $\mathcal{E}$ Management, 46(3), 167-174. https://doi.org/10.1016/j.im.2009.01.002

Megginson, L. C., Mosley, D. C., \& Pietri, P. H. (2001). Supervisory management: The art of empowering and developing people. South-Western College sPub.

Mishra, K., Boynton, L., \& Mishra, A. (2014). Driving employee engagement: The expanded role of internal communications. International Journal of Business Communication, 51(2), 183-202. https://doi.org/10.1177/2329488414525399

Mobley, W. H. (1977). Intermediate linkages in the relationship between job satisfaction and employee turnover. Journal of applied psychology, 62(2), 237.

Mossholder, K. W., Settoon, R. P., \& Henagan, S. C. (2005). A relational perspective on turnover: Examining structural, attitudinal, and behavioral predictors. Academy of Management Journal, 48(4), 607-618. https://doi.org/10.5465/amj.2005.17843941

Moynihan, D. P., Pandey, S. K., \& Wright, B. E. (2012). Setting the table: How transformational leadership fosters performance information use. Journal of Public Administration Research and Theory, 22(1), 143-164. https://doi.org/10.1093/jopart/mur024

Naz, S., \& Gul, S. (2014). Moderating role of organizational commitment between communication satisfaction and turnover intentions among nurses. Pakistan Journal of Psychological Research, 39-52.

Palanski, M., Avey, J. B., \& Jiraporn, N. (2014). The effects of ethical leadership and abusive supervision on job search behaviors in the turnover process. Journal of Business Ethics, 121, 135-146. https://doi.org/10.1007/s10551-013-1690-6

Parris, D. L., \& Peachey, J. W. (2013). A systematic literature review of servant leadership theory in organizational contexts. Journal of business ethics, 113(3), 377-393. https://doi.org/10.1007/s10551-012-1322-6

Pocztowski, A. (2007). Zarzadzanie zasobami ludzkimi. Strategie-procesy-metody (pp. 176-177). PWE, Warszawa.

Porter, L. W., \& Steers, R. M. (1973). Organizational, work, and personal factors in employee turnover and absenteeism. Psychological bulletin, 80(2), 151. https://doi.org/10.1037/h0034829

Price, J. L., \& Mueller, C. W. (1981). A causal model of turnover for nurses. Academy of management journal, 24(3), 543-565. https://doi.org/10.5465/255574

Purohit, M. (2016). A study on-employee turnover in IT sector with special emphasis on Wipro and Infosys. IOSR Journal of Business and Management, 18(4), 47-51.

Rhoades, L., Eisenberger, R., \& Armeli, S. (2001). Affective commitment to the organization: The contribution of perceived organizational support. Journal of applied psychology, 86(5), 825. https://doi.org/10.1037/00219010.86.5.825

Rong, G., \& Grover, V. (2009). Keeping up to date with information technology: Testing a model of technological knowledge renewal effectiveness for IT professionals. Information \& Management, 46(7), 376-387. https://doi.org/10.1016/j.im.2009.07.002

Rubenstein, A. L., Eberly, M. B., Lee, T. W., \& Mitchell, T. R. (2018). Surveying the forest: A meta-analysis, moderator investigation, and future-oriented discussion of the antecedents of voluntary employee turnover. Personnel Psychology, 71(1), 23-65. https://doi.org/10.1111/peps.12226

Scarnati, J. T. (2001). On becoming a team player. Team performance management: An International journal. 7(1/2), 5-10 https://doi.org/10.1108/13527590110389501

Schaap, P., \& Olckers, C. (2020). Relationships between employee retention factors and attitudinal antecedents of voluntary turnover: An extended structural equation modelling approach. SA Journal of Human Resource Management, 18, 15. https://doi.org/10.4102/sajhrm.v18i0.1358

Sendjaya, S., \& Pekerti, A. (2010). Servant leadership as antecedent of trust in organizations. Leadership $\mathcal{E}$ Organization Development Journal. 31(7), 643-663 https://doi.org/10.1108/01437731011079673

Spaho, K. (2013). Organizational communication and conflict management. Management-Journal of Contemporary Management Issues, 18(1), 103-118. 
Suifan, T. S., Diab, H., Alhyari, S., \& Sweis, R. J. (2020). Does ethical leadership reduce turnover intention? The mediating effects of psychological empowerment and organizational identification. Journal of Human Behavior in the Social Environment, 30(4), 410-428. https://doi.org/10.1080/10911359.2019.1690611

Sun, R., \& Wang, W. (2017). Transformational leadership, employee turnover intention, and actual voluntary turnover in public organizations. Public Management Review, 19(8), 1124-1141. https://doi.org/10.1080/14719037.2016.1257063

Steers, R., \& Mowday, R. (1981). Employee turnover and post decision accommodation processes. In L. L. Cummings, \& B. Staw (Eds.), Research in organizational behavior (Vol. 3., pp. 235-281) Greenwich, CT: JAI.

Stovel, M., \& Bontis, N. (2002). Voluntary turnover: knowledge management-friend or foe? Journal of intellectual Capital, 3(3), 303-322. https://doi.org/10.1108/14691930210435633

Tariszka-Semegine, E. (2012). Organizational internal communication as a means of improving efficiency. European Scientific Journal, 8(15). https://doi.org/10.14267/veztud.2015.02.07

Tarricone, P., \& Luca, J. (2002). Successful teamwork: A case study.

Tews, M. J., Michel, J. W., \& Ellingson, J. E. (2013). The impact of coworker support on employee turnover in the hospitality industry. Group E Organization Management, 38(5), 630-653. https://doi.org/10.1177/1059601113503039

Thatcher, J. B., Stepina, L. P., \& Boyle, R. J. (2002). Turnover of information technology workers: Examining empirically the influence of attitudes, job characteristics, and external markets. Journal of Management Information Systems, 19(3), 231-261.

Thatcher, J. B., Liu, Y., Stepina, L. P., Goodman, J. M., \& Treadway, D. C. (2006). IT worker turnover: An empirical examination of intrinsic motivation. ACM SIGMIS Database: the DATABASE for Advances in Information Systems, 37(2-3), 133-146. https://doi.org/10.1145/1161345.1161361

Thwala, W. D., Ajagbe, A. M., Enegbuma, W. I., \& Bilau, A. A. (2012). Sudanese small and medium sized construction firms: An empirical survey of job turnover. Journal of Basic and Applied Scientific Research, 2(8), 7414-7420.

Trevor, C. O., Gerhart, B., \& Boudreau, J. W. (1997). Voluntary turnover and job performance: Curvilinearity and the moderating influences of salary growth and promotions. Journal of applied psychology, 82(1), 44. https://doi.org/10.1037/0021-9010.82.1.44

Turgut, H., Bekmezci, M., \& Ateş, M. F. (2017). The moderating role of job satisfaction on the relationship between servant leadership and turnover intention. Journal of Business Research Turk, 9(2), 300-314. https://doi.org/10.20491/isarder.2017.273

Uhl-Bien, M., Graen, G. B., \& Scandura, T. A. (2000). Implications of leader-member exchange (LMX) for strategic human resource management systems: Relationships as social capital for competitive advantage. Research in personnel and human resources management, 18, 137-186.

Van Dierendonck, D., Stam, D., Boersma, P., De Windt, N., \& Alkema, J. (2014). Same difference? Exploring the differential mechanisms linking servant leadership and transformational leadership to follower outcomes. Leadersh Q, 25(3), 544-562. https://doi.org/10.1016/j.leaqua.2013.11.014

Von Hagel, W. J. 2009. Precipitating events leading to voluntary employee turnover among information technology professionals: a qualitative phenomenological study. Doctor's dissertation. University of Phoenix.

Viswesvaran, C., Sanchez, J. I., \& Fisher, J. (1999). The role of social support in the process of work stress: A meta-analysis. Journal of vocational behavior, 54(2), 314-334. https://doi.org/10.1006/jvbe.1998.1661

Wang, X., Sun, L., Sheeran, L. K., Sun, B. H., Zhang, Q. X., Zhang, D., ... \& Li, J. H. (2016). Social rank versus affiliation: Which is more closely related to leadership of group movements in Tibetan macaques (Macaca thibetana)? American journal of primatology, 78(8), 816-824.

Wang, Y. D., \& Sung, W. C. (2016). Predictors of organizational citizenship behavior: Ethical leadership and workplace jealousy. Journal of Business Ethics, 135(1), 117-128. https://doi.org/10.1002/ajp.22546

Zand, D. E. (1997). The leadership triad: Knowledge, trust, and power. Oxford University Press on Demand.

Zhao, W., \& Zhou, X. (2008). Intraorganizational career advancement and voluntary turnover in a multinational bank in Taiwan. Career Development International. https://doi.org/10.1108/13620430810891446 